Jurnal Ekonomi Pembangunan

Volume 11, Nomor 2,Desember 2010, hlm.149-159

\title{
THE RELATIONSHIP BETWEEN ECONOMIC GROWTH AND GOVERNMENT SPENDING: A CASE STUDY OF OIC COUNTRIES
}

\author{
Heri Sudarsono \\ Fakultas Ekonomi Universitas Islam Indonesia \\ Jalan Condongcatur Lingkar Utara Yogyakarta Indonesia
}

Diterima 20 Oktober 2010/Disetujui 5 Nopember 2010

\begin{abstract}
This paper presents the results for testing for causal relationship between economic growth and goverment spending for OIC countries covering the time series data 1970 2006. There are usually two propositions regarding the relation between economic growth and government spending: Wagner's Law states that as GDP grows, the public sector tends to grow; and the Keynesian framework postulates that public expenditure causes GDP to grow. The primary strength and originality of this paper is that we used aggregate data as well as disaggregate data for Granger causality test. By testing for causality between economic growth and government spending, we find that government spending does cause economic growth in Iran, Nigeria and Tunisia, which are compatible with Keynesian's theory. However, the economic growth does cause the increase in goverment spending in Algeria, Burkina Faso, Benin, Indonesia, Libya Malaysia, Marocco, and Saudi, which are well-suited with Wagner's law.
\end{abstract}

Keywords: granger test, government spending, Wagner's law, Keynesian

\begin{abstract}
Abstrak: Makalah ini menyajikan hasil pengujian hubungan kausal antara pertumbuhan ekonomi dan pengeluaran pemerintah bagi negara-negara OKI dengan data time series 1970 2006. Biasanya ada dua dalil/proposisi mengenai hubungan antara pertumbuhan ekonomi dan pengeluaran pemerintah yaitu pertama Hukum Wagner yang menyatakan bahwa pada waktu Produk Domestik Bruto tumbuh, sektor publik cenderung untuk tumbuh, dan kedua kerangka Keynesian mendalilkan bahwa pengeluaran publik menyebabkan Produk Domestik Bruto tumbuh. Kekuatan utama makalah in adalah peneliti menggunakan data agregat dan disagregat untuk pengujian kausalitas Granger. Pengujian kausalitas antara pertumbuhan ekonomi dan pengeluaran pemerintah menemukan bahwa pengeluaran pemerintah menyebabkan pertumbuhan ekonomi terjadi di negara-negara; Iran, Nigeria, dan Tunisia dan ini sesuai dengan teori Keynesian. Sedangkan pertumbuhan ekonomi menyebabkan kenaikan pengeluaran pemerintah terjadi di negara-negara; Aljazair, Burkina Faso, Benin, Indonesia, Libya Malaysia, Maroko, dan Saudi, sebagaimana hukum Wagner.
\end{abstract}

Kata kunci: uji granger, pengeluaran pemerintah, Hukum Wagner, Keynesian

\section{INTRODUCTION}

The relationship between economic growth and goverment spending has been a topic for research in public finance and macroeconomic modeling (Easterly \& Rebelo, 1993; Kolluri, Panik \& Wahab, 2000. In public finance the research studies have focused on understanding the causes of growth of the public sector. Whereas, the macroeconomic modeling has been on analyzing the short and long term impact of government spending policies on economic growth. Understanding the effect of government spending on economic growth gives an insight into the possible effect of fiscal adjustment policies on correction the fiscal deficit. 
One set of studies has been directed toward assessing the effect of the general flow of government services on private decision making and, more specifically, on the impact of government spending on long-run economic growth. Especially, the Keynesian theory suggest that government spending accelerate economic growth. These theoretical models are reviews so as to have an insight into their relevance in explaining the impact of fiscal adjustment policies on economic growth.

According to the Keynesian model, government spending is autonomous and exogenous (Branson, 1979; Levacic \& Rebmann, 1991). Thus, government spending is identified as a policy tool to influence economic growth and short term output fluctuations. The Keynesian model stated that government spending cuts or the reduction of a fiscal deficit result in a decline in aggregate demand an income directly. The further affect aggregate demand through the negative multiplier effect. The results of effect are a decline in economic growth and an increase in unemployment.

The other set of studies has explored the principal cause of growth in the public sector. Wagner's law is one of the earliest attempts that emphasises economic growth as the fundamental determinant of public sector growth. Wagner proposed three reasons why the share of government spending would increase in importance as an economy grows. First, as industrialization progresses public sector activity will substitute for private sector activity because state's administrative and protective functions would increase in importance during the industrialization process. State's role in maintaining law and order as well as its role in activities related to economic regulation is likely to become more pronounced due to the increasing complexity of economic life and urbanization.

Furthermore, in assumption in Wagner's work, goverment spending would also increase as a country industrializes because of the high income elasticity of demand for these services. This means that as per capita income increases demand for the services mentioned above, which are usually provided by the government spending increases rapidly, raising the share of public sector expenditure in GDP. Finally, technological change and growing scale of firms would tend to create monopolies whose effects the state will have to offset. The remainder of the paper is organized as follows; a brief review of the related literature is in section 2. The methodology is presented in section 3, section 4 describes the data and empirical results, and conclusions are discussed in the final section.

Empirical literature. The Keynesian model's proposition that government spending affects output growth, empirical studies suggest that the composition of government spending determines its impact on economic growth (Kolluri, Panik \& Wahab, 2000). Ansari (1993) in his study of the applicability of Keynesian theory in Canada found an increase in government spending on health was positively associated with GDP growth. Ansari (1993) also observed that payments for government debt were positively related to GDP growth. In another study, Biswal, Dhawan, \& Lee (1999) also observed that government debt repayments were associated with an increase in GDP growth.

Despite the evidence highlighted above on the effect of government spending on output growth, government spending may have no effect on output growth. Ansari, Gordon and Akuamoah (1997) found that increase in government spending was not associated with output growth in Kenya, Ghana, and South Africa, which their study to validate the Keynesian hypothesis in those countries. Al-Faris (2002) also presented similar findings in his study of the relationship between government spending and economic growth using a Keynesian model the Gulf countries.

Al-Faris (2002) found a negative relationship between government spending and economic growth in African economies may be attributed to a number of factors. Government spending on defense, subsidies and wages has a insignificant impact on productivity and on output growth. Therefore, an increase in government spending on unproductively categories in not expected to result in the rise of output growth. Then, government spending in education and health takes a long time before the effected on productivity and economic growth are realized. While, an increase in government 
spending has an effect on output growth if the budget constraint is binding (Kweka \& Morrissey, 2000). An increase in government spending when a government faces a soft budget constraint accelerates inflation and negatively affects output growth. Thus, for an increase in public spending to have a positive impact on output growth, the fiscal deficit need to be constraint and budget constraint be binding

Ram (1986) and Grossman (1988) found a positive relationship between government spending and economic growth, despite of the disaggregation of expenditures. Diamond (1989) observed that social expenditure exhibited a positive significant impact on growth in the short-run whilst infrastructure expenditure had less influence (albeit positive). In addition, he found that capital expenditure had a negative influence on economic growth. He attributed this negative relationship to a long gestation period and inefficiency associated with these of public funds. Furthermore, Devarajan and Vinaya (1993) found a negative and insignificant relationship between productive expenditure and economic growth, while Lin (1994) found that nonproductive spending had a negative and insignificant impact on industrialized countries but a significant positive impact for developing countries.

Islam (2001) in his re-examination of Wagner's hypothesis for the USA found that the relative size of government expenditures and real Gross National Product per capita are cointegrated by using Johansen-Juselius's cointegration approach. Moreover, Wagner's hypothesis is strongly supported by the result of Engle-Granger (1987) error correction approach. Singh and Sahni (1984) use the Granger causality test to determine the causality direction between national income and public expenditures in India. Data used in the study were annual and deflated by using implicit national income deflator. The study finds no causal process confirming the Wagnerian or the opposite view

Finally, Abizadeh and Yousefi (1998) use South Korean data to test Wagner's law. They first conduct Granger type causality tests, and then estimate a growth equation and a government expenditure growth equation by using annual data for the period of 1961-1992. They exclude government expenditures from the GDP to obtain the private sector GDP, and use this in their tests. After comparing the results from the estimations authors conclude that government expenditures did not contributed to economic growth in Korea.

\section{RESEARCH METHOD}

The methodology to be used in this study will be based from Granger causality model (Granger, 1990). This helps in avoiding the problem of omission of variables, which was existent in some earlier studies. These two variables are known in macroeconomics to be important in the determination of both economic growth and government spending. To use the causality test, the variables under consideration are required to be stationary.

The Granger test will be used here because it is a very simple test, which has been widely accepted as a reliable test for causality between two variables. Almost all the studies mentioned in the literature review have used this test and this has shed more light to us on how the test can be used for economies of different sizes and situations. The procedure here is used to detect the causality in the context of both the bivariate model and multivariate model. The simplest Granger causality test is:

$$
\begin{aligned}
& \ln Y_{t}=b_{0}^{\prime}+\sum_{i=t}^{n} b_{1 i}^{\prime} \ln Y_{t-1}+\sum_{i=1}^{n} b_{2 i}^{\prime} \ln G_{t-i}+e_{t}^{\prime} \\
& \ln Y_{t}=\alpha_{0}^{\prime}+\sum_{i=t}^{n} \alpha_{1 i}^{\prime} \ln G_{t-1}+\sum_{i=1}^{n} \alpha_{2 i}^{\prime} \ln Y_{t-i}+u_{t}^{\prime}
\end{aligned}
$$

where $\ln Y_{t}$ is the natural logarithm of real per capita GDP, and $\ln \mathbf{G}_{\mathbf{t}}$ is the natural logarithm of government spending. $\mathbf{e}_{\mathbf{t}} \mathbf{t}$ and $\mathbf{u}_{\mathbf{t}}^{\prime}$ are white noise error terms. The null hypothesis for equation 1 is that $\ln G$ does not Granger cause $\ln Y$. This hypothesis would be rejected if the coefficients of the lagged Gs (summation of $b_{2 i}$ as a group) are found to be jointly significant. The null hypothesis for equation 2 is that 'In $\mathrm{Y}$ does not Granger cause ln G'. This hypothesis would be rejected if the coefficients of the lagged Ys (summation of '2i as a group) are found to be 
jointly significant. If both of these null hypotheses are rejected, then a bi-directional

In the error correction model, the relevant error-correction terms (ECt-1) are included in the standard Granger causality procedure after all variables have been made stationary by differencing, which yields equations 3 and 4 .

$$
\begin{aligned}
\Delta \ln Y_{t}= & b_{0}^{\prime}+\sum_{i=t}^{n} b_{1 i}^{\prime} \Delta \ln Y_{t-1}+\sum_{i=1}^{n} b_{2 i}^{\prime} \Delta \ln G_{t-i}- \\
& b_{3} E C_{t-1}+e_{t}^{\prime} \\
\Delta \ln G_{t}= & \alpha_{0}^{\prime}+\sum_{i=t}^{n} \alpha_{1 i}^{\prime} \Delta \ln G_{t-1}+\sum_{i=1}^{n} \alpha_{2 i}^{\prime} \Delta \ln Y_{t-i}{ }^{-} \\
& \alpha_{3} E C_{t-1}+u_{t}^{\prime}
\end{aligned}
$$

where is first difference operator, $\mathbf{e}_{\mathbf{t}}$ and $\mathbf{u}_{\mathbf{t}}$ are white noise error terms. The independent variables are said to 'cause' the dependent variable if the error correction term (ECt-1) is significant ( $b_{3}$ or $a_{3}$ are nonzero) or the coefficients of the lagged independent variables (summation of $b_{2 i}$ in equation 3 or summation of $a_{2 i}$ in equation 4 ) are jointly significant. However, if the series are not cointegrated, Granger test is carried out without the error correction terms.

\section{RESULTS AND DISCUSSION}

We apply the methodology described above to annual data from Algeria. Iran, Jordan, and Syrian over the period 1970-2005 and annual data from Benin, Burkina Faso, Conte Divora, Egypt, Indonesia, Kuwait, Libya, Malaysia, Morocco, Nigeria, Pakistan, Saudi, and Tunisia over the period 1970-2006. The variables used and their definitions are as follows, $Y$ is the economic growth and $\mathrm{G}$ is the total government spending.

As a preliminary data analysis, all series are first checked for stationary. If the series are nonstationary, standard econometric techniques can lead to misleading results. Both the PhillipsPerron tests for a unit root are performed on each individual series. Table 1 reports the results of the unit-root tests that allow of include in the test use test for unit root in level in first level. The results in Table 1 indicate that all the series are trend stationary.
Before applying the Johansen's cointegration procedure, it is necessary to determine the lag length of the VAR equation which should be high enough to ensure that the errors are approximately white noise but small enough to allow estimation, In this paper is chosen on the basis ofthe minimum value of Akaike Information Criterion (AIC).

Since the variables used in all the cases are non-stationary, I(1), we perform a cointegration test to find out whether a linear combination of these series converge to an equilibrium or not. Two series (variables) are said to be cointegrated if they each are non-stationary, at least I(1), and if their linear combination converges to an equilibrium. (Engle and Granger, 1987) This means that cointegrated variables have a long term equilibrium relationship. Johansen and Juselius's (1990) cointegration method was used for cointegration analysis. The cointegration and causality tests were carried out only on the first-difference stationary variables, I(1). Johansen and Juselius, procedure test results are presented in Table 2

The test statistics fail to reject the null hypothesis of no cointegrating relation at 5 per cent significance level, except in the case of Algeria, Burkina Faso, Indonesia, Marocco, Nigeria, and Saudi. This indicates that in Benin, CoteDivor, Egypt, Iran, Jordan, Kuwait, Libya, Malaysia, Pakistan, Syrian and Tunisia there is no long run relationship between economic growth and government spending over the sample period. However, the two variables are found to be cointegrated in the case of Algeria, Burkina Faso, Indonesia, Morocco, Nigeria, and Saudi's data.

In the Table 3 reported that the Granger causality test results obtained by vector auto regression (VAR) approach for Benin, CoteDivor, Egypt, Iran, Jordan, Kuwait, Libya, Malaysia, Pakistan, Syrian and Tunisia. The VAR regression do not include error correction term since we find that the variables are not cointegrated for these countries. The Wagner's hypothesis is not supported for these countries. There is no evidence supporting the reverse hypothesis for CoteDivor, Egypt, Jordan, Kuwait, Pakistan, and Syrian. However, reverse hypothesis is empirically supported by Benin, 
Table 1. Philip Peron Unit Root Result

\begin{tabular}{|c|c|c|c|c|}
\hline Country & Variable & Unit root statistic level & First difference & Degree of integration \\
\hline \multirow{2}{*}{ Algeria } & $\operatorname{Ln} Y$ & -2.660 & $-11.313^{*}$ & $\mathrm{I}(1)$ \\
\hline & $\operatorname{Ln} G$ & -2.786 & $-18.891^{*}$ & $\mathrm{I}(1)$ \\
\hline \multirow{2}{*}{ Benin } & $\operatorname{Ln} Y$ & -1.919 & $-11.396^{*}$ & $\mathrm{I}(1)$ \\
\hline & $\operatorname{Ln} G$ & -2.316 & $-10.076^{*}$ & $\mathrm{I}(1)$ \\
\hline \multirow{2}{*}{ Burkina Faso } & $\operatorname{Ln} Y$ & -0.800 & $-6.891^{*}$ & $\mathrm{I}(1)$ \\
\hline & $\operatorname{Ln} G$ & -6.223 & $-6.780^{*}$ & $\mathrm{I}(1)$ \\
\hline \multirow{2}{*}{ Conte Divor } & $\operatorname{Ln} Y$ & -2.257 & $-19.880^{*}$ & $\mathrm{I}(1)$ \\
\hline & $\operatorname{Ln} G$ & -2.901 & $-8.244^{*}$ & $\mathrm{I}(1)$ \\
\hline \multirow{2}{*}{ Egyp } & $\operatorname{Ln} Y$ & -1.385 & $-3.210^{* *}$ & $\mathrm{I}(1)$ \\
\hline & $\operatorname{Ln} G$ & -0.322 & $-6.708^{*}$ & $\mathrm{I}(1)$ \\
\hline \multirow{2}{*}{ Indonesia } & $\operatorname{Ln} Y$ & -1.572 & $-11.172^{*}$ & $\mathrm{I}(1)$ \\
\hline & $\operatorname{Ln} G$ & -2.227 & $-7.750^{*}$ & $\mathrm{I}(1)$ \\
\hline \multirow{2}{*}{ Iran } & $\operatorname{Ln} Y$ & -1.858 & $-21.634^{*}$ & $\mathrm{I}(1)$ \\
\hline & $\operatorname{Ln} G$ & -1.825 & $-8.975^{\star}$ & $\mathrm{I}(1)$ \\
\hline \multirow{2}{*}{ Jordan } & $\operatorname{Ln} Y$ & -2.506 & $-9.111^{*}$ & $\mathrm{I}(1)$ \\
\hline & $\operatorname{Ln} G$ & -2.838 & $-22.750^{*}$ & $\mathrm{I}(1)$ \\
\hline \multirow{2}{*}{ Kuwait } & $\operatorname{Ln} Y$ & -1.819 & $-5.651^{*}$ & $\mathrm{I}(1)$ \\
\hline & $\operatorname{Ln} G$ & -1.445 & $-6.245^{*}$ & $\mathrm{I}(1)$ \\
\hline \multirow{2}{*}{ Libya } & $\operatorname{Ln} Y$ & -1.169 & $-5.541^{*}$ & $\mathrm{I}(1)$ \\
\hline & $\operatorname{Ln} G$ & -1.117 & $-6.951^{*}$ & $\mathrm{I}(1)$ \\
\hline \multirow{2}{*}{ Malaysia } & $\operatorname{Ln} Y$ & -1.884 & $-4.845^{*}$ & $\mathrm{I}(1)$ \\
\hline & $\operatorname{Ln} G$ & -1.189 & $-5.727^{\star}$ & $\mathrm{I}(1)$ \\
\hline \multirow{2}{*}{ Marocco } & $\operatorname{Ln} Y$ & -2.132 & $-25.070^{*}$ & $\mathrm{I}(1)$ \\
\hline & $\operatorname{Ln} G$ & -3.633 & $-34.125^{*}$ & $\mathrm{I}(1)$ \\
\hline \multirow{2}{*}{ Nigeria } & $\operatorname{Ln} Y$ & -1.188 & $-8.753^{\star}$ & $\mathrm{I}(1)$ \\
\hline & $\operatorname{Ln} G$ & -1.320 & $-27.273^{*}$ & $\mathrm{I}(1)$ \\
\hline \multirow{2}{*}{ Pakistan } & $\operatorname{Ln} Y$ & -2.919 & $-9.187^{*}$ & $\mathrm{I}(1)$ \\
\hline & $\operatorname{Ln} G$ & -2.206 & $-45.269^{*}$ & $\mathrm{I}(1)$ \\
\hline \multirow{2}{*}{ Saudi } & $\operatorname{Ln} Y$ & -3.805 & $-13.428^{*}$ & $\mathrm{I}(1)$ \\
\hline & $\operatorname{Ln} G$ & -4.325 & $-14.257^{*}$ & $\mathrm{I}(1)$ \\
\hline \multirow{2}{*}{ Syrian } & $\operatorname{Ln} Y$ & -2.455 & $-3.991^{*}$ & $\mathrm{I}(1)$ \\
\hline & $\operatorname{Ln} G$ & -7.306 & $-4.062^{*}$ & $\mathrm{I}(1)$ \\
\hline \multirow{2}{*}{ Tunisia } & $\operatorname{Ln} Y$ & -2.134 & $-17.268^{*}$ & $\mathrm{I}(1)$ \\
\hline & $\operatorname{Ln} G$ & -1.799 & $-9.906^{*}$ & $\mathrm{I}(1)$ \\
\hline
\end{tabular}

Note: * and ${ }^{* *}$ denotes $1 \%$ and $5 \%$ significant level based on Mac Kinnon's critical values In levels regressions constant and time trend were included into unit root regression In the regression with first difference only the constant was included

Iran, Libya, Malaysia and Tunisia' data. The hypothesis that growth of government spending does not Granger cause growth of economic growth is rejected at 5 per cent significant level.

In the case of Algeria, Burkina Faso, Indonesia, Morocco, Nigeria, and Saudi, the two series converge in the long run, that is $\ln G$ and $\ln Y$ are cointegrated, standard Granger causality approach (VAR approach) can not be used to yield approximate result. So, in Appendix 1 reported that we do the Granger test with error correction terms from the cointegrating equations included in a regression that also includes once differenced variables $(\Delta \ln Y$ and $\Delta \ln G)$. Results are reported in Algeria, Indonesia, Nigeria and Saudi are found to be significant at 5 per cent level over the different lag length of 1 , 2, 3, 4 years in one side. Furthermore, our finding that there is causality link, one-way or twoway, between economic growth and government spending in Algeria, Benin, Burkina Faso, Iran, Libya, Malaysia, Morocco, Nigeria, Saudi, dan Tunisian. However, the other countries are not causality link, like CoteDivor, Egypt, Jordan, Kuwait, Morocco, Pakistan and Syrian. 


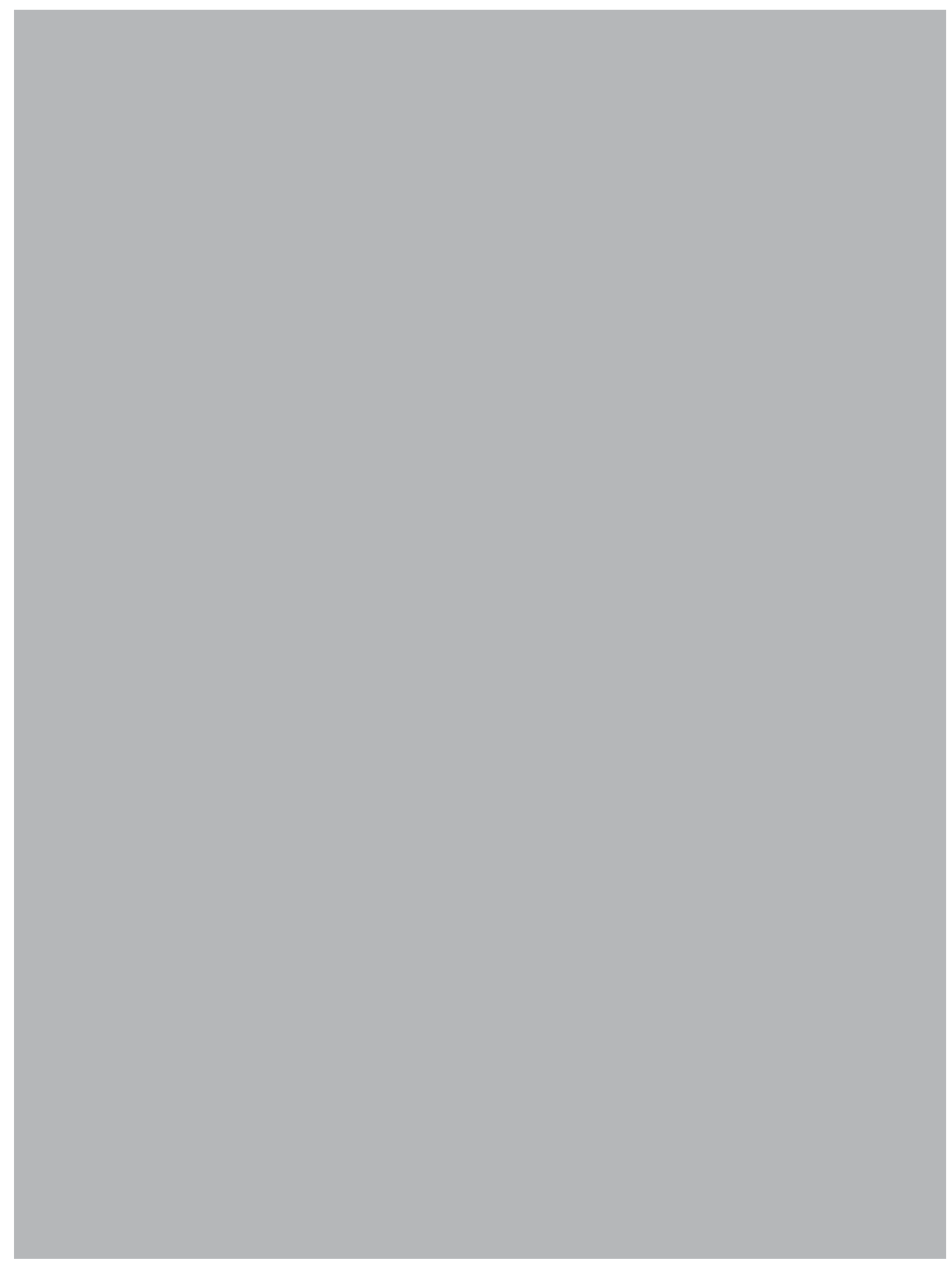


Table 3. Granger Causality Test Result via VAR

\begin{tabular}{|c|c|c|c|}
\hline $\begin{array}{c}\text { Lag length } \\
\text { Null Hypothesis }\end{array}$ & $\begin{array}{c}1 \\
\text { F-statistic }\end{array}$ & $\begin{array}{c}2 \\
\text { F-Statistic }\end{array}$ & $\begin{array}{c}3 \\
\text { F-Statistic }\end{array}$ \\
\hline $\begin{array}{l}\text { LnG Benin does not Granger Cause } \ln Y \\
\text { LnY Benin does not Granger Cause } \ln G\end{array}$ & $\begin{array}{c}3.389 \\
(0.074) \\
5.320 \\
(\mathbf{0 . 0 2 7})^{* *}\end{array}$ & - & - \\
\hline $\begin{array}{l}\text { LnG CoteDivor does not Granger Cause } \ln Y \\
\text { LnY CoteDivor does not Granger Cause } \ln G\end{array}$ & $\begin{array}{l}0.414 \\
(0.524) \\
1.641 \\
(0.209)\end{array}$ & - & - \\
\hline $\begin{array}{l}\text { LnG Egypt does not Granger Cause } \ln Y \\
\text { LnY Egypt does not Granger Cause } \ln G\end{array}$ & $\begin{array}{c}2.280 \\
(0.140) \\
2.646 \\
(0.113)\end{array}$ & - & - \\
\hline $\begin{array}{l}\text { LnG Iran does not Granger Cause } \ln Y \\
\text { LnY Iran does not Granger Cause } \ln G\end{array}$ & $\begin{array}{l}10.735 \\
(0.002)^{*} \\
2.560 \\
(0.119)\end{array}$ & $\begin{array}{l}3.453 \\
(0.045)^{* *} \\
2.592 \\
(0.092)\end{array}$ & - \\
\hline LnG Jordan does not Granger Cause $\ln Y$ & $\begin{array}{c}2.587 \\
(0.118)\end{array}$ & $\begin{array}{c}0.558 \\
(0.578)\end{array}$ & $\begin{array}{c}0.695 \\
(0.564)\end{array}$ \\
\hline LnY Jordan does not Granger Cause lnG & $\begin{array}{c}2.193 \\
(0.148)\end{array}$ & $\begin{array}{c}0.643 \\
(0.533)\end{array}$ & $\begin{array}{c}0.704 \\
(0.558)\end{array}$ \\
\hline LnG Kuwait does not Granger Cause $\ln Y$ & $\begin{array}{l}1.127 \\
(0.296)\end{array}$ & - & - \\
\hline LnY Kuwait does not Granger Cause $\ln G$ & $\begin{array}{c}0.628 \\
(0.433)\end{array}$ & & \\
\hline LnG Libya does not Granger Cause $\ln Y$ & $\begin{array}{c}0.932 \\
(0.341)\end{array}$ & - & - \\
\hline LnY Libya does not Granger Cause $\ln G$ & $\begin{array}{c}12.448 \\
(\mathbf{0 . 0 0 1})^{*}\end{array}$ & & \\
\hline LnG Malaysia does not Granger Cause $\ln Y$ & $\begin{array}{c}0.896 \\
(0.350)\end{array}$ & - & - \\
\hline LnY Malaysia does not Granger Cause $\ln G$ & $\begin{array}{c}4.948 \\
(0.033)^{* *}\end{array}$ & & \\
\hline LnG Pakistan does not Granger Cause $\ln Y$ & $\begin{array}{c}2.565 \\
(0.119)\end{array}$ & $\begin{array}{c}1.463 \\
(0.247)\end{array}$ & $\begin{array}{c}0.800 \\
(0.504)\end{array}$ \\
\hline LnY Pakistan does not Granger Cause ln G & $\begin{array}{l}2.473 \\
(0.125)\end{array}$ & $\begin{array}{c}0.578 \\
(0.567)\end{array}$ & $\begin{array}{c}0.382 \\
(0.766)\end{array}$ \\
\hline LnG Syrian does not Granger Cause $\ln Y$ & $\begin{array}{c}0.736 \\
(0.397)\end{array}$ & - & - \\
\hline LnY Syrian does not Granger Cause $\operatorname{lnG}$ & $\begin{array}{c}2.301 \\
(0.139)\end{array}$ & & \\
\hline LnG Tunisia does not Granger Cause $\ln Y$ & $\begin{array}{c}16.254 \\
(0.000)^{*}\end{array}$ & $\begin{array}{c}5.912 \\
(\mathbf{0 . 0 0 7})^{*}\end{array}$ & $\begin{array}{c}3.198 \\
(0.039) * *\end{array}$ \\
\hline LnY Tunisia does not Granger Cause $\operatorname{lnG}$ & $\begin{array}{c}7.346 \\
(0.010)^{* *}\end{array}$ & $\begin{array}{c}2.911 \\
(0.070)\end{array}$ & $\begin{array}{c}2.878 \\
(0.055)\end{array}$ \\
\hline
\end{tabular}

Note: Probability in (.) and * and ** denotes $1 \%$ and $5 \%$ siqnificant level

Inability of the government to increase taxes beyond a certain level would also prevent government spending from keeping pace with national income since how much the government can increase its spending is determined by its revenues. This argument was same with
Peacock and Wiseman (1967), whereas that tax rates are fixed because of political and social forces, and then, the behavior towards tax rates would only change in a severe crisis such as war. In the absence of such a crisis or shock government spending will not increase unless 
the demand for public sector services is highly income-elastic.

Another way in which economic growth or industrialization could reduce the rate of increase in tax revenues, thereby making it more difficult to detect a possible link between industrialization and government spending has been noted in Ferris and West (1996). Kau and Rubin (1981) explained that due to economic growth a larger proportion of the labor force in a country might get transferred to less visible earnings and be able to avoid paying taxes. A specific example of a process that would generate such a transfer is urbanization, which in Kau and Rubin's framework is a measure of the larger set of opportunities available to closely located tax payers to avoid formal markets through such activities as barter.

\section{CONCLUSION}

This paper presents the results for testing for causal relationship between economic growth and government spending for OIC government covering the time series data from 1970 until 2005 and 2006. There are usually two propositions regarding the relation between economic growth and government spending: Wagner's Law states that as GDP grows, the public sector tends to grow; and the Keynesian framework postulates that public expenditure causes GDP to grow. The primary strength and originality of this paper is that we used aggregate data as well as disaggregate data for Granger causality test. By testing for causality between economic growth and government spending, we find that government spending does cause economic growth in Iran, Nigeria and Tunisia, which are compatible with Keynesian's theory. However, the economic growth does cause the increase in government spending in Algeria, Burkina Faso, Benin, Indonesia, Libya Malaysia, Morocco, and Saudi are well-suited with Wagner's law.

Finally, judging from the above mentioned results, in terms of government spending, the causality test suggested that economic growth in OIC countries has more influence on government spending than the other way round. In other words, Wagner's law is generally more prominent than Keynesian theory in some OIC countries.

\section{REFERENCES}

Agell, J., T. Lindh and H. Ohlsson. 1999. Growth and the Public Sector: a Reply, European Journal of Political Economy, Vol. 15, No.2, pp. 359-366.

Al-Faris, A.F. 2002. Public Expenditure and Economic Growth in the Gulf Cooperation Council Countries, Applied Economics, Vol. 34, pp. 1187-1193.

Ansari, M, Gordon, D. V. and Akuamoah, C. 1997. Keynes versus Wagner: Public Expenditure and National Income for Three African Countries. Applied Economics, Vol. 29, pp. 543-550.

Ansari, M. 1993. Testing the Relationship between Government Expenditure and National Income in Canada, Employing Granger Causality and Cointegration Analysis, Managerial Finance, Vol. 19, pp. 31-47.

Branson, H. 1979. Macroeconomic Theory and Policy. New York/London: Harper and Row Publishers.

Devarajan, S. and S. Vinaya. 1993. What do Governments Buy? The Composition of Public Spending and Economic Performance, Policy Research Working Paper, The World Bank, WPS 1082.

Diamond, J. 1989. Government Expenditure and Economic Growth: An Empirical Investigation. IMF Working Paper No. 89/45, Washington D.C.

Ferris J.S. and West, E. 1996. Testing Theories of Real Government Size: US Experience 1959-1989, Southern Economic Journal, Vol. 62 , pp. 537-553.

Granger, C.W.J. 1990. Introduction in Granger, C.W.J (ed) Modeling Economic Series: Advanced Texts in Econometrics, Oxford University Press.

Grossman, P.J. 1983. Government and Eco- 
nomic Growth. A Non- Linear Relationship. Public Choice, Vol. 56, pp. 193-200.

Islam, Anisul, M. 2001. Wagner's Law Revisited: Cointegration and Exogeneity Tests for the USA. Applied Economics Letters, Vol. 8, pp. 509-515.

Kau J.B. and P.H. Rubin. 1981. The Size of Government. Public Choice, Vol. 37, pp. 261274.

Kolluri, B. R., Panik, M. J. and Wahab, M. S. 2000. Government Expenditure and Economic Growth: Evidence from G7 Countries. Applied Economics, Vol. 32, pp. 10591068.

Kweka, J. and O. Morrissey. 2000. Government Spending and Economic Growth in Tanzania, 1965-1996. University of Nottingham, CREDIT Research Paper 00/06.

Levacic, R.and Rebmann, A. 1991. Macroecono- mics. An Introduction to Keynesian-Neoclassical Controversies. Second Edition. London: Macmillan.

Peacock, A.T. and Wiseman, J. 1961. the Growth of Public Expenditure in the United Kingdom, Princeton: Princeton University Press

Phillips, P.C.B., and P. Perron. 1988. Testing for a Unit Root in Time Series Regression. Biometrica, Vol. 75, pp. 335-46.

Ram. 1986. Government size and Economic Growth: A New Framework and Some Empirical Evidence from Cross-Sectional and Time Series Data. American Economic Review, Vol 76, No.1, pp 191-203.

Singh, B. and Sahni, B. S. 1984. Causality between Public Expenditure and National Income. the Review of Economics and Statistics, Vol. 66, pp. 630-644. 
Appendix 1. Granger Causality Test Results via Error Correction Model (ECM)

\begin{tabular}{|c|c|c|c|c|c|c|c|c|c|c|c|c|}
\hline Country & \multicolumn{2}{|c|}{$\begin{array}{l}\text { Algeria } \\
\text { CointEq1 }\end{array}$} & \multicolumn{2}{|c|}{ Burkina Faso } & \multicolumn{2}{|c|}{ Indonesia } & \multicolumn{2}{|c|}{ Marocco } & \multicolumn{2}{|c|}{ Nigeria } & \multicolumn{2}{|c|}{ Saudi } \\
\hline $\operatorname{Ln} \mathrm{Y}$ & \multicolumn{2}{|c|}{1.000} & \multicolumn{2}{|c|}{$\begin{array}{l}\text { CointEq1 } \\
1.000\end{array}$} & & & 1.0 & & 1.00 & & & \\
\hline LnG & \multicolumn{2}{|c|}{$\begin{array}{l}-0.780 \\
(0.067)\end{array}$} & \multicolumn{2}{|c|}{$\begin{array}{l}-1.023 \\
(0.065)\end{array}$} & \multicolumn{2}{|c|}{$\begin{array}{l}-0.915 \\
(0.092)\end{array}$} & \multicolumn{2}{|c|}{$\begin{array}{l}-1.136 \\
(0.157)\end{array}$} & \multicolumn{2}{|c|}{$\begin{array}{c}-1.074 \\
(0.042)\end{array}$} & -1.397 & \\
\hline C & \multicolumn{2}{|c|}{-3.779} & \multicolumn{2}{|c|}{-1.4069} & \multicolumn{2}{|c|}{-2.873} & \multicolumn{2}{|c|}{-0.812} & \multicolumn{2}{|c|}{-2.178302} & \multicolumn{2}{|c|}{1.881} \\
\hline CointEq1 & $\begin{array}{c}\text { LnY } \\
-0.237 \\
(0.336) \\
{[0.704]}\end{array}$ & $\begin{array}{c}\text { LnG } \\
1.498 \\
(0.400) \\
{[3.741]^{* *}}\end{array}$ & $\begin{array}{c}\text { LnY } \\
0.019 \\
(0.082) \\
{[0.236]}\end{array}$ & $\begin{array}{c}\text { LnG } \\
0.394 \\
(0.088) \\
{[4.449]^{*}}\end{array}$ & $\begin{array}{c}\text { LnY } \\
-0.028 \\
(0.250) \\
{[-0.115]}\end{array}$ & $\begin{array}{c}\text { LnG } \\
0.981 \\
(0.257) \\
{[3.816]^{* *}}\end{array}$ & $\begin{array}{c}\text { LnY } \\
-0.119 \\
(0.194) \\
{[-0.613]}\end{array}$ & $\begin{array}{l}\text { LnG } \\
0.859 \\
(0.279) \\
{[3.077]^{* *}}\end{array}$ & $\begin{array}{c}\text { LnY } \\
0.020 \\
(0.367) \\
{[0.054]}\end{array}$ & $\begin{array}{l}\text { LnG } \\
2.083 \\
(0.551) \\
{[3.779]^{* *}}\end{array}$ & $\begin{array}{c}\text { LnY } \\
-0.053 \\
(0.158) \\
{[-0.336]}\end{array}$ & $\begin{array}{c}\text { LnG } \\
0.683 \\
(0.187) \\
{[3.640]^{* *}}\end{array}$ \\
\hline $\operatorname{LnY}(1)$ & $\begin{array}{l}-0.512 \\
(0.240) \\
{[-2.131]^{* *}}\end{array}$ & $\begin{array}{c}-0.731 \\
(0.285) \\
{[-2.558]^{* *}}\end{array}$ & $\begin{array}{c}-0.238 \\
(0.215) \\
{[-1.107]}\end{array}$ & $\begin{array}{c}-0.270 \\
(0.232) \\
{[-1.165]}\end{array}$ & $\begin{array}{c}-0.509 \\
(0.255) \\
{[-1.996]}\end{array}$ & $\begin{array}{l}-0.786 \\
(0.262) \\
{[-2.992]^{* *}}\end{array}$ & $\begin{array}{c}-0.447 \\
(0.195) \\
{[-2.284]^{* *}}\end{array}$ & $\begin{array}{c}-0.385 \\
(0.281) \\
{[-1.372]}\end{array}$ & $\begin{array}{c}-0.677 \\
(0.360) \\
{[-1.881]}\end{array}$ & $\begin{array}{c}-1.695 \\
(0.540) \\
{[-3.133]^{* *}}\end{array}$ & $\begin{array}{c}-0.659 \\
(0.150) \\
{[-4.369]^{* * *}}\end{array}$ & $\begin{array}{c}-0.454 \\
(0.178) \\
{[-2.543]^{* *}}\end{array}$ \\
\hline $\operatorname{LnY}(2)$ & - & - & $\begin{array}{c}-0.186 \\
(0.199) \\
{[-0.933]}\end{array}$ & $\begin{array}{l}-0.514 \\
(0.214) \\
{[-2.393]^{* *}}\end{array}$ & $\begin{array}{c}-0.231 \\
(0.198) \\
{[-1.166]}\end{array}$ & $\begin{array}{c}-0.289 \\
(0.204) \\
{[-1.419]}\end{array}$ & - & - & $\begin{array}{c}-0.401 \\
(0.313) \\
{[-1.281]}\end{array}$ & $\begin{array}{c}-1.258 \\
(0.470) \\
{[-2.674]^{* *}}\end{array}$ & - & - \\
\hline $\operatorname{LnY}(3)$ & - & - & $\begin{array}{c}0.0165 \\
(0.203) \\
{[0.081]}\end{array}$ & $\begin{array}{c}-0.301 \\
(0.218) \\
{[-1.377]}\end{array}$ & - & - & - & - & $\begin{array}{c}-0.181 \\
(0.230) \\
{[-0.789]}\end{array}$ & $\begin{array}{c}-0.962 \\
(0.345) \\
{[-2.783]^{* *}}\end{array}$ & - & - \\
\hline $\operatorname{LnY}(4)$ & - & - & $\begin{array}{c}-0.038 \\
(0.191) \\
{[-0.203]}\end{array}$ & $\begin{array}{l}-0.519 \\
(0.206) \\
{[-2.516]^{* *}}\end{array}$ & - & - & - & - & $\begin{array}{c}-0.071 \\
(0.209) \\
{[-0.342]}\end{array}$ & $\begin{array}{l}0.035 \\
(0.314) \\
{[0.111]}\end{array}$ & - & - \\
\hline $\operatorname{LnG(1)}$ & $\begin{array}{c}-0.062 \\
0.165) \\
{[-0.378]}\end{array}$ & $\begin{array}{c}-0.006 \\
(0.197) \\
{[-0.032]}\end{array}$ & $\begin{array}{c}-0.097 \\
(0.132) \\
{[-0.739]}\end{array}$ & $\begin{array}{c}-0.144 \\
(0.142) \\
{[-1.015]}\end{array}$ & $\begin{array}{c}-0.063 \\
(0.187) \\
{[-0.338]}\end{array}$ & $\begin{array}{c}0.191 \\
(0.193) \\
{[0.989]}\end{array}$ & $\begin{array}{c}-0.060 \\
(0.152) \\
{[-0.395]}\end{array}$ & $\begin{array}{c}-0.018 \\
(0.219) \\
{[-0.083]}\end{array}$ & $\begin{array}{l}0.065 \\
(0.307) \\
{[0.214]}\end{array}$ & $\begin{array}{l}1.070 \\
(0.461) \\
{[2.320]^{* *}}\end{array}$ & $\begin{array}{c}0.0491 \\
(0.167) \\
{[0.292]}\end{array}$ & $\begin{array}{c}0.050 \\
(0.198) \\
{[0.252]}\end{array}$ \\
\hline $\operatorname{LnG(2)}$ & - & - & $\begin{array}{c}-0.018 \\
(0.136) \\
{[-0.133]}\end{array}$ & $\begin{array}{c}-0.026 \\
(0.146) \\
{[-0.182]}\end{array}$ & $\begin{array}{c}0.092 \\
(0.168) \\
{[0.551]}\end{array}$ & $\begin{array}{l}0.103 \\
(0.172) \\
{[0.597]}\end{array}$ & - & - & $\begin{array}{l}0.249 \\
(0.251) \\
{[0.991]}\end{array}$ & $\begin{array}{l}0.879 \\
(0.377) \\
{[2.326]^{* *}}\end{array}$ & - & - \\
\hline $\operatorname{LnG(3)}$ & - & - & $\begin{array}{l}0.139 \\
(0.135) \\
{[1.024]}\end{array}$ & $\begin{array}{c}-0.067 \\
(0.146) \\
{[-0.459]}\end{array}$ & - & - & - & - & $\begin{array}{l}0.157 \\
(0.202) \\
{[0.776]}\end{array}$ & $\begin{array}{c}0.591 \\
(0.303) \\
{[1.947]}\end{array}$ & - & - \\
\hline $\operatorname{LnG(4)}$ & - & - & $\begin{array}{l}0.314 \\
(0.136) \\
{[2.301]^{* *}}\end{array}$ & $\begin{array}{l}0.371 \\
(0.147) \\
{[2.527]^{* *}}\end{array}$ & - & - & - & - & $\begin{array}{r}0.067174 \\
(0.13736) \\
{[0.48904]}\end{array}$ & $\begin{array}{l}0.284 \\
(0.206) \\
{[1.377]}\end{array}$ & - & - \\
\hline C & $\begin{array}{c}0.077 \\
0.214) \\
{[0.360]}\end{array}$ & $\begin{array}{l}0.230 \\
(0.255) \\
{[0.901]}\end{array}$ & $\begin{array}{l}0.101 \\
(0.066) \\
{[1.519]}\end{array}$ & $\begin{array}{l}0.263 \\
(0.072) \\
{[3.658]}\end{array}$ & $\begin{array}{l}0.316 \\
(0.174) \\
{[1.811]}\end{array}$ & $\begin{array}{c}0.323 \\
(0.179) \\
{[1.801]}\end{array}$ & $\begin{array}{c}0.137 \\
(0.151) \\
{[0.911]}\end{array}$ & $\begin{array}{l}0.143 \\
(0.217) \\
{[0.663]}\end{array}$ & $\begin{array}{c}0.437991 \\
(0.17542) \\
{[2.49683]}\end{array}$ & $\begin{array}{l}0.395 \\
(0.263) \\
{[1.502]}\end{array}$ & $\begin{array}{c}0.244 \\
(0.173) \\
{[1.408]}\end{array}$ & $\begin{array}{c}0.168 \\
(0.205) \\
{[0.821]}\end{array}$ \\
\hline $\begin{array}{l}\text { R-squred } \\
\text { Adj. R- } \\
\text { squared } \\
\text { F-statistic }\end{array}$ & $\begin{array}{c}0.377 \\
0.310 \\
5.648\end{array}$ & $\begin{array}{l}0.546 \\
0.497 \\
11.237\end{array}$ & $\begin{array}{l}0.317 \\
0.024 \\
1.084\end{array}$ & $\begin{array}{l}0.640 \\
0.485 \\
4.150\end{array}$ & $\begin{array}{l}0.271 \\
0.136 \\
2.011\end{array}$ & $\begin{array}{l}0.423 \\
0.316 \\
3.963\end{array}$ & $\begin{array}{l}0.259 \\
0.185 \\
3.501\end{array}$ & $\begin{array}{l}0.430 \\
0.374 \\
7.573\end{array}$ & $\begin{array}{l}0.521 \\
0.306 \\
2.426\end{array}$ & $\begin{array}{l}0.739 \\
0.622 \\
6.322\end{array}$ & $\begin{array}{l}0.483 \\
0.431 \\
9.342\end{array}$ & $\begin{array}{l}0.463 \\
0.409 \\
9.342\end{array}$ \\
\hline
\end{tabular}

Notes: Standard for error in (.) and t-statistic in [.] and * and ** denotes $1 \%$ and 5\% siqnificant level

Appendix 2. Plots of Series of Economic Growth (Y) and Goverment Spending (G)
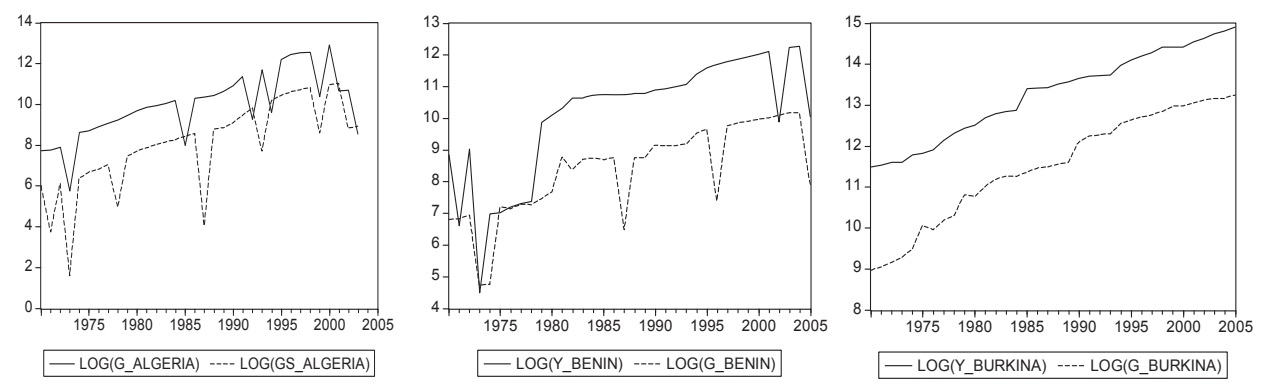

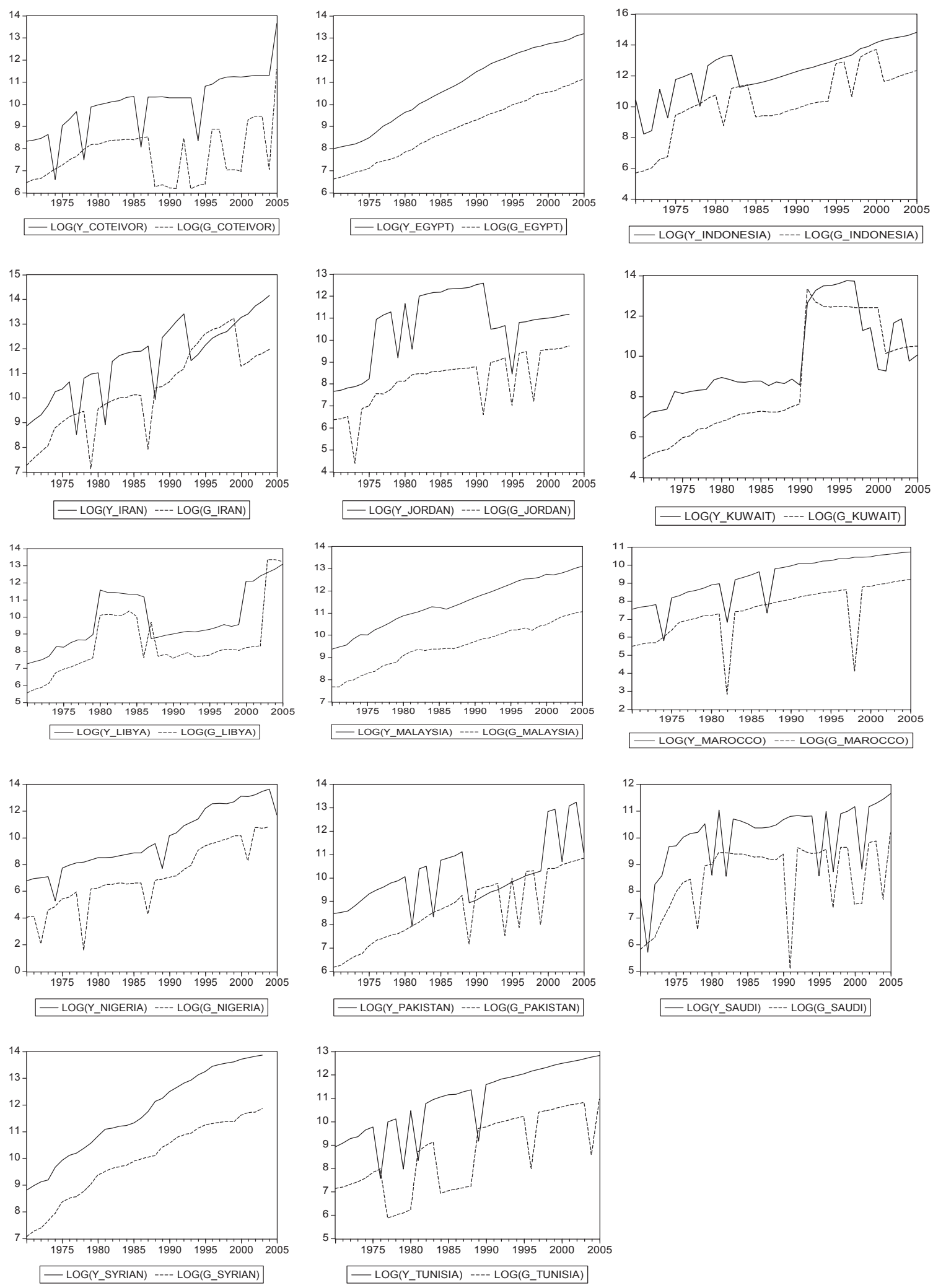